UDC 338.2:351.777.61:005.932 JEL: R49, Q58

\section{Alina Kodzhebash}

Institute of Market Problems and Economic \& Ecological Research of the NAS of Ukraine,

Odessa, Ukraine

E-mail: alinakod130@gmail.com orcid.org/0000-0002-8161-632X

\section{Alexander Krivencev}

LLC "UMWELT Ukraine",

Lünen, Germany

E-mail: krivencev@freenet.de orcid.org/0000-0003-0012-0371

Received: November, 2018

Accepted: December, 2018

DOI:10.31520/2616-7107/2018.2.4-9

(C) Economics. Ecology. Socium, 2018 CC BY-NC 4.0 license

\section{TRANSPORT AND LOGISTIC COMPONENTS OF WASTE MANAGEMENT STRATEGIES IN THE CONTEXT OF IMPLEMENTING RESOURCE-SAVING AND ENVIRONMENTAL POLICY}

Introduction. The overall situation in the field of waste management in Ukraine is extremely difficult, which is explained by the lack of preventive resource conservation and environmental protection policies, as well as the lack of financing of measures aimed at eliminating the negative consequences resulting from the increasing generation of waste. In particular, due to insufficient financing of landfill contents: there are violations of the schedules of their sanitary cleaning, which leads to the formation of spontaneous landfills in the territories of residential development, especially in rural areas; there are cases of chaotic accumulation of waste that is not compacted and not filled with soil; most landfills and the surrounding area have a terrible look. The general state of waste in Ukraine highlights the urgency and seriousness of the problem of domestic and industrial waste management.

Aim and tasks. The purpose of the article is to substantiate the role and disclosure of the peculiarities of the transport and logistics component of waste management strategies in the context of implementing resource-saving and environmental policy in Ukraine.

Results. As a result of the research it is determined that the reform of the waste management system is necessary, which envisages solving of such key organizational, economic and managerial tasks in the context of realization of resource saving and environmental protection policy in Ukraine. The organizational and economic directions of waste management reform are: effective implementation of separate waste collection; construction of new landfills and waste treatment plants; information and institutional support for issues related to waste management; economically justified tariff formation ; stabilization of the finance industry through the introduction of a system of fines for violating legislation, in particular, on the separate collection of waste and the transfer of funds received to the development of the industry, investments provided by state guarantees on the return of capital invested by the investor.

Conclusions. At present the reform of the waste management system is necessary by means of solving a series of interrelated organizational, economic and managerial tasks in the context of implementation of resource conservation and environmental protection policy in Ukraine. In particular, it is about the need for financial stabilization of the industry, the expediency of strengthening regulatory instruments and, at the same time, motivational instruments, etc. Based on the analysis of the relationship between these objectives and the objectives of environmental policy, in particular in the field of transport and logistics, as well as the content and constituents of waste management strategies in Ukraine, it was concluded that there is a need for an integrated approach to determine the role and place of transport-logistic component.

Keywords: waste, transport logistics, organizational and economic tasks, management strategy, environmental policy. 


\section{УДК 338.2:351.777.61:005.932 JEL: R49, Q58}

\section{Аліна Коджебаш}

Інститут проблем ринку та економіко-екологічних досліджень НАН України, Одеса, Україна E-mail: alinakod130@gmail.com orcid.org/0000-0002-8161-632X

\section{Олександр Крівенцев \\ TOB «UMWELT Україна» (REMONDIS group) \\ Люнен, Німеччина \\ E-mail: krivencev@freenet.de}

Отримано: Листопад, 2018

Прийнято: Грудень, 2018

DOI:10.31520/2616-7107/2018.2.4-9

(C) Економіка. Екологія. Соціум, 2018 CC BY-NC 4.0 ліцензія

\section{ТРАНСПОРТНО-ЛОГІСТИЧНА СКЛАДОВА СТРАТЕГІЙ ПОВОДЖЕННЯ 3 ВІДХОДАМИ В КОНТЕКСТІ РЕАЛІЗАЦЇ̈ РЕСУРСОЗБЕРІГАЮЧОЇ ТА ПРИРОДООХОРОННОЇ ПОЛІТИКИ}

Проблема. Загальна ситуація в сфері поводження 3 відходами в Україні характеризується недостатністю превентивної ресурсозберігаючої та природоохоронної політики, так і недофінансуванням заходів, спрямованих на усунення негативних наслідків унаслідок все більш масштабного утворення відходів. Зокрема, у зв'язку 3 недостатнім фінансуванням утримання сміттєзвалищ: порушуються графіки їх санітарної очистки, що призводить до утворення стихійних звалищ на територіях житлової забудови, особливо в сільській місцевості; наявні випадки хаотичного накопичення відходів, які не ущільнюються та не засипаються грунтом; більшість сміттєзвалищ i прилегла до них територія мають жахливий вигляд. Загальний стан справ з відходами в Україні підкреслює актуальність та гостроту проблеми поводження 3 побутовими та промисловими відходами.

Мета і завдання. Мета статті полягає в обгрунтуванні ролі та розкритті особливостей транспортно-логістичної складової стратегій поводження 3 відходами в контексті реалізації ресурсозберігаючої та природоохоронної політики в Україні.

Результати. Як результат проведеного дослідження встановлено, що необхідне реформування системи управління відходами, яке передбачає вирішення таких ключових організаційно-економічних та управлінських завдань у контексті реалізації ресурсозберігаючої та природоохоронної політики в Україні. До організаційних та економічних напрямів реформування системи управління відходами відносяться: впровадження ефективного роздільного збору відходів; будівництво нових полігонів і сміттєпереробних заводів; інформаційне та інституційне забезпечення питань, пов'язаних із сферою поводження 3 відходами. економічно обгрунтоване тарифоутворення; стабілізація фінансування галузі через упровадження системи штрафів за порушення законодавства, зокрема, про роздільний збір відходів і спрямування одержаних коштів на розвиток галузі; інвестування, забезпечене державними гарантіями на повернення вкладеного інвестором капіталу.

Висновки. Станом на сьогоднішній день необхідне реформування системи управління відходами за допомогою вирішення низки взаємопов'язаних організаційно-економічних та управлінських завдань у контексті реалізації ресурсозберігаючої та природоохоронної політики в Україні. Зокрема, йдеться про необхідність фінансової стабілізації галузі, доцільність посилення регуляторних інструментів і водночас мотиваційних інструментів тощо. На основі проведеного аналізу взаємозв'язків між цими завданнями та цілями екологічної політики, зокрема, в галузі транспорту та логістики, а також змісту та складових стратегій поводження 3 відходами в Україні, зроблено висновок про необхідність інтегрованого підходу щодо визначення ролі та місця в них транспортно-логістичної складової.

Ключові слова: відходи, транспортна логістика, організаційно-економічні завдання, стратегія управління, 
екологічна політика, Україна.

Introduction. The overall situation in the field of waste management in Ukraine is extremely difficult, which is explained by the lack of preventive resource conservation and environmental protection policies, as well as the lack of financing of measures aimed at eliminating the negative consequences resulting from the increasing generation of waste. In particular, due to insufficient financing of landfill contents [1]: there are violations of the schedules of their sanitary cleaning, which leads to the formation of spontaneous landfills in the territories of residential development, especially in rural areas; there are cases of chaotic accumulation of waste that is not compacted and not filled with soil; most landfills and the surrounding area have a terrible look.

According to the Minister of Ecology and Natural Resources of Ukraine O. Semerak [2], every year in the country about 10 tons of waste per person are generated, which is almost twice as much as in EU countries, “... about 36 billion tons of waste have been accumulated, which is more than 50 thousand tons per 1 square kilometer", while only $30 \%$ of industrial and $4 \%$ of household waste are utilized, "... the area of unauthorized dumps increases".

Overall statistics on waste generation and treatment of them in Ukraine [3, 107-148] shows that during the period 2014-2017 years, every year on average: 332 million tons (a total 1.33 billion tons) of waste were generated; 7.77 tons of waste were formed on one person; about 11 million tons were collected (totaling 0.05 billion tons).

The tragedy at the landfill in Hrybovychy near Lviv [4] and the general state of waste in Ukraine highlights the urgency and seriousness of the problem of domestic and industrial waste management. It is vital for Ukraine to build and implement an effective waste management system.

Analysis recent research and publications. Scientific works, devoted to a wide range of issues related to the formation and implementation of resource conservation and environmental policy, are implemented, in particular, by such authors as B. V. Burkinsky, A. I. Martienko, N. I. Khumarova (concerning to the institutional aspects of the administration of the sphere of natural resources [5-6], the preservation of natural resources as the dominant ecologization of regional development [7]), V. M. Kysly, M. M. Petrushenko, O. V. Prokopenko, H. M. Shevchenko (concerning to the socionatural and economic contradictions [8], as well as economic evaluation of natural resources, in particular, recreational in the transformational conditions of management [910]) and many others.

D.V. Lyko, I.V. Hushchuk

[1], M.M. Orfanova, O.I. Ivanyk [11], T. Kharchenko, Yu. Sagaidak [12], I.S. Semenenko, O.V. Suprunenko [13], N.I. Khumarova [14] and others disclosed strategic and other aspects of waste management in their scientific works. Analysis of transport and logistics systems in the framework of ecological and economic development is carried out in works [15-18] and by such scientists as V. V. Braginsky [19], V. V. Lyfar [20], M. Yu. Hryhorak, $\mathrm{Yu}$. M. Chichkan-Khlipovka [21] and others.

At the same time, in our view, transport and logistics as a component of waste management strategies require a more detailed study and substantiation of proposals for their economic and environmental development.

Aim and tasks. The purpose of the article is to substantiate the role and disclosure of the peculiarities of the transport and logistics component of waste management strategies in the context of implementing resource-saving and environmental policy in Ukraine.

Results. Consequently, as of today, the reform of the waste management system is necessary, which in our opinion envisages solving of such key organizational, economic and managerial tasks in the context of realization of resource saving and environmental protection policy in Ukraine [1; $11-12 ; 22 ; 23,93-95 ; 24-26]$ :

1) organizational tasks:

- effective implementation of separate waste collection. In our opinion, the issue is not only in the process of organization of municipal self-government separate collection of waste, in particular, the purchase and installation of containers for separate collection, etc. The question is much deeper: the majority of the 
population is not prepared to systematically, and even more so, to initiate the implementation of requirements related to the introduction of a new waste management system. On the other hand, legislation on the collection and sorting of secondary raw materials remains unprotected. Accordingly, the executive authorities should intensify social work to explain to people the expediency and peculiarities of the implementation of a separate collection of household waste. (For example, in each Ukrainian apartment there is no additional place for placement of capacities for separate accumulation of waste, etc.);

- construction of new landfills and waste treatment plants. It is clear that under other circumstances, new landfills would be unnecessary as they occupy an additional area and require significant construction and maintenance costs. However, existing dumps and landfills Ukraine, which gets a significant portion of waste, are over-loaded (sometimes far beyond the documented limits), often equipped by outdated standards and inadequately exploited, the result of which is the pollution of the environment and damage to the health of the population. Therefore, in the face of the need for decisive action on the part of the authorities and the inadequate financing opportunities for large-scale projects (such as the construction of waste processing plants), new landfills are exactly a real solution to the problem of waste, taking into account the compliance of the characteristics of the landfills with modern world standards and situational factors for waste management in specific settlements.

The construction of waste processing plants, which requires considerably more investment than construction of landfills, is still a distant prospect for Ukraine. There is a hope that the first such project will be implemented during 2019-2021, namely the waste recycling complex in Lviv [27]. The project is funded and controlled by the EBRD; "The enterprise will process $65-70 \%$ of the total amount of garbage coming from the city (Lviv collects about 600 tons of waste daily). The rest are planned to be baked and transport to the briquetted waste landfills. The estimated cost of the plant and the reclamation of the landfill in
Hrybovychy is 35 million euro";

- institutional support for issues related to waste management. It is advisable to concentrate these issues within the competence of a single government body (ministry): as of today, two ministries deal with these issues at the same time (the Ministry of Ecology and Natural Resources and the Ministry of Regional Development, Construction and Housing and Communal Services of Ukraine), which causes inconsistency and duplication in the implementation of waste management policies.

Also, given the high level of innovation in the industry, it is advisable to create an institution subordinated to this body, which would address the following issues at the professional scientific and applied level [22]: harmonization of Ukraine with the EU legislation in the field of waste management; exchange of experience, participation in training programs, roundtables, symposia, etc. in the field of waste management; allocation of land for the construction of landfills, sorting lines, waste processing and incineration plants; interaction with the authorities regarding licensing and approval of tariffs for waste management activities; development and improvement of the industry; interaction with all stakeholders (the population, representatives of industry and business, self-government bodies, potential foreign and domestic investors, scientists, etc.);

- comprehensive information support for activities related to the development of waste management. These tasks should be performed not only by local authorities or the relevant ministry, but all participants in the process of waste generation and management. It is clear that there will be some asymmetry of information concerning, for example, the actual costs of waste disposal or transportation. The need for integrated information provision should be understood as the distribution, accessibility, transparency and clarity of information on environmental impacts, hazard issues, specifics of sorting, etc. in respect for waste (for example, a large proportion of the population in Ukraine still does not know the color of a container that corresponds to one or another type of waste, and also where waste from specific containers is directed, etc.); 
2) economic tasks:

- pricing that takes place on a competitive basis [23]: municipal authorities should clearly understand what the result should be achieved in waste management and, accordingly, prepare a project based on the budget principle of costeffectiveness (calculation and comparison of the costs of providing services by municipalities or with the involvement of private companies in the form of public-private partnership). Thus, the waste disposal costs must exceed the cost of any other process of handling them; for this, we can use environmental tax as a tool to increase the level of safety of waste management;

- economically justified tariff formation as one of the key factors for making managerial decisions in the field of waste management in a particular locality or region. The complexity of the tariff formation process in Ukraine is connected with some bureaucracy when we are presenting the documents and reviewing it by local authorities for tariff approval. Tariff setting processes may be delayed for several months, in spite of the existence of objective and legally foreseeable reasons for increasing costs of the carrier company. Accordingly, it is another obstacle to financial planning and ensuring timely and quality public services in the field of waste management. Therefore, it is necessary to approve a separate tariff for the provision of services for the transportation of secondary raw materials on sorting lines or to increase the single tariff for the transportation of waste, taking into account the expenses of the carrier company for the collection, transportation and sorting of secondary raw materials. It is also advisable to introduce a "green tariff" for electricity producers from solid household wastes [12];

-stabilization of the finance industry: on the one hand, through the introduction of a system of fines for violating legislation, in particular, on the separate collection of waste and the transfer of funds received to the development of the industry (introduction of an adequate system of administrative and economic regulation of separate collection and other processes of waste management will allow to get a significant increase of attention from the side of the population), on the other hand, through a review of the budget policy of the industry at all its levels, and the intensification of grant activities(the state must understand that today waste management requires permanent preventive approach primarily reflected in increased financial resources aimed at stabilization and development of the industry);

-investments provided by state guarantees on the return of capital invested by the investor, namely, due to the following factors: improved, directed towards the interests of the investor, legislative framework, long-term performance of contracts and guarantee payment for services rendered, increase of attractiveness of investment objects. At the same time, the attraction of private investment should be understood in an inseparable combination with the effectiveness of interaction between all stakeholders in the waste management market in Ukraine. "As long as the authorities do not hear the views of the market participants on household waste management, the investment climate in the country is unlikely to change for the better" [22]. The point is that domestic and foreign investors before investing their money in a particular business project in the field of waste management, should feel guarantees from the side of the state to protect their business interests and return the investment and calculate with a high probability the estimated value of the efficiency of investments;

3) management tasks:

-strategic planning, which provides an institutional mechanism for implementing of plansforthedevelopmentofwastemanagementwit hintheframeworkofthedevelopmentofterritoriale conomicandecologicalsystems [26];

-regulation of the market of handling of secondary raw materials from the side of the state, primarily regarding the restoration of licensing activities for the collection, sorting and sale of secondary raw materials(for example, during the period 2009-2013 Enterprise Ltd "Umwelt Ukraine" [28] implemented its own system of separate collection of about 3 thousand containers in Kyiv, Zaporizhia and Cherkasy. In 2013, licensing of collection and sorting of secondary raw materials was canceled, which led to the emergence of so-called "gray" operators in the secondary raw materials market. 
Accordingly, the activities of "Umwelt Ukraine" became unprofitable and eventually stopped due to a significant decrease of storage containers of recycled materials. Simply put: "At the moment, secondary raw materials from tanks are removed before the arrival of garbage trucks and gets through the illegal points of admission to the shadow market" [22].

Administrative and management tasks, related to the regulatory function, should also have a more narrow focus, in particular regarding environmental and economic risks in the field of waste management [25];

-increasing control [24] over the activities of local governments, public organizations and businesses in the area of waste management, the restoration of permanent monitoring observations [1] of waste disposal sites, any sanctioned and spill dumps, as well as areas where industrial waste is located. A special role belongs to the local selfgovernment authorities responsible for organizing the collection, transportation, storage, recycling and disposal of solid municipal and other wastes generated on the territory in the settlement. In addition, the competence of these authorities is to issue permits for the construction of waste management facilities, in particular, waste recycling and waste incinerators. Accordingly, they are responsible for the elimination of both legal and non-legal landfills (because of the tragedy that occurred in Velyki Hrybovychy near Lviv village council at an extraordinary session decided to close the landfill completely) [4];

-the prioritization of motivational tools and activities that are not only and not so much complement regulatory function, and have interest and thus produce various kinds of proactive activities in the field of waste management. In particular, it refers to preferential loans, preferential taxation, targeted subsidies, image events, etc.

At the table 1 below, you can characterize the relationship between organizational and economic tasks in the field of waste management with the goals of resource conservation and environmental policy, as well as environmental policy in the transport and logistics industry.

Table 1. Interconnection of the environmental policy objectives, particularly in transport and logistics, organizational and economic problems of waste management

\begin{tabular}{|c|c|c|c|}
\hline Tasks Objectives & Resource-saving policy & $\begin{array}{l}\text { Environme } \\
\text { protection } \mathrm{p}\end{array}$ & $\begin{array}{l}\text { Environmental policy in the field of } \\
\text { transport and logistics }\end{array}$ \\
\hline \multicolumn{4}{|l|}{ Organizational tasks } \\
\hline $\begin{array}{l}\text { Effective separate } \\
\text { collection of waste }\end{array}$ & $\begin{array}{l}\text { Maximum pres } \\
\text { of valuable st } \\
\text { by types of resc }\end{array}$ & $\begin{array}{l}\text { Minimizing } \\
\text { environmental pollution } \\
\text { during waste collection }\end{array}$ & $\begin{array}{l}\text { Ecologization of a complex of } \\
\text { organizational and transport } \\
\text { processes of waste collection }\end{array}$ \\
\hline $\begin{array}{l}\text { Construction of } \\
\text { landfills and waste } \\
\text { processing plants }\end{array}$ & $\begin{array}{l}\text { Maximizing } \\
\text { opportunities } \\
\text { "green" energy }\end{array}$ & $\begin{array}{l}\text { Maximum preservation } \\
\text { of environmental quality } \\
\text { for the current situation }\end{array}$ & $\begin{array}{l}\text { Optimization of transport routes } \\
\text { from places of waste collection to } \\
\text { landfills and waste recycling }\end{array}$ \\
\hline Institutional support & \multicolumn{2}{|c|}{$\begin{array}{l}\text { Optimization of legislative, coordination and } \\
\text { research activities }\end{array}$} & $\begin{array}{l}\text { Actualization of ecological } \\
\text { management in the industry }\end{array}$ \\
\hline $\begin{array}{l}\text { Comprehensive } \\
\text { information support }\end{array}$ & \multicolumn{2}{|c|}{$\begin{array}{l}\text { Optimization of processes for collecting, } \\
\text { processing and storing data and information flows } \\
\text { on waste management }\end{array}$} & $\begin{array}{l}\text { Maximum consistency } \\
\text { information and transport flows }\end{array}$ \\
\hline \multicolumn{4}{|l|}{ Economic tasks } \\
\hline $\begin{array}{l}\text { Pricing on a } \\
\text { competitive basis in } \\
\text { the field of waste } \\
\text { management }\end{array}$ & $\begin{array}{l}\text { zing the loss of } \\
\text { es in } \operatorname{cost} \\
\text { on }\end{array}$ & $\begin{array}{l}\text { Prioritization of eco- } \\
\text { security in the formation } \\
\text { of costs }\end{array}$ & $\begin{array}{l}\text { Optimization of transport and } \\
\text { logistics costs in the price structure } \\
\text { for waste management services }\end{array}$ \\
\hline $\begin{array}{l}\text { Economically } \\
\text { justified tariff setting } \\
\text { for services }\end{array}$ & $\begin{array}{l}\text { Compensation of costs } \\
\text { related to the actions } \\
\text { for } \\
\text { resources }\end{array}$ & $\begin{array}{l}\text { Compensation for } \\
\text { damage caused by } \\
\text { environmental pollution }\end{array}$ & $\begin{array}{l}\text { Compensation of the environmental } \\
\text { component in the structure of } \\
\text { transport and logistics costs }\end{array}$ \\
\hline $\begin{array}{l}\text { Stabilizing } \\
\text { finance industry }\end{array}$ & $\begin{array}{l}\text { Optimization } \\
\text { resource } \\
\text { budgeting }\end{array}$ & $\begin{array}{l}\text { Maximization of fines } \\
\text { for environmental } \\
\text { damage }\end{array}$ & $\begin{array}{l}\text { Optimal combination of fiscal } \\
\text { incentives and penalties }\end{array}$ \\
\hline it & $\begin{array}{l}\text { Minimizing the risks in } \\
\text { the legal field }\end{array}$ & $\begin{array}{l}\text { Maximize the promotion } \\
\text { of eco-safe activities }\end{array}$ & $\begin{array}{l}\text { Activation of actions aimed at } \\
\text { ecologizing the image of the industry }\end{array}$ \\
\hline
\end{tabular}

Source: developed by authors. 
The tasks indicated in Table 1 are generalized and detailed (clear definition of terms, sources of funding, nature of implementation, specific moments, etc.) in programs and strategies of economic and ecological development at different levels of their implementation. We are interested, first of all, in specifying these tasks in connection with the transport and logistics component of such strategies. Transportation and logistics component of the National Strategy of waste management [29] is reflected in such moments (and corresponding stages of implementation):

-drafting of bills on decommissioned vehicles used in waste management processes (first stage);

-development of electronic information provision of logistic plans of production and use of natural resources and waste management (second stage);

-ensuring the functioning of the electronic information logistic scheme for the extraction of natural resources, the receipt of useful products from them, the generation of waste that is recycled and utilized (third stage);

- construction of a network of garbage reloading stations in order to reduce transportation costs in the field of household waste (third stage);

- provision of operational control over the transportation of industrial waste with the implementation of appropriate measures for the safety and protection of the environment during the transportation of industrial waste (third stage);

- creation of a system of collection and transportation of hazardous waste (third stage);

-development and installation of technical specifications and technological instructions for the collection, storage and transportation of animal waste (third stage);

-development and implementation of economic instruments for encouraging the collection, transportation and use of agricultural waste of vegetable origin as raw materials for combustion with coal at thermal power plants (third stage);

-development and introduction of mechanisms for providing subsidies for the collection and transportation of plant wastes suitable for the production of feed for animal fattening (third stage); -collection, storage and transportation of agricultural waste of animal origin; research the availability and adequacy of infrastructure and availability of services for the collection, storage and transportation of such wastes (third stage);

-implementation extended producer responsibility scheme, which will include: requirements for conducting the state register, in which manufacturers of electrical and electronic equipment must be registered; entities engaged in the collection, transportation, preparation for reuse, recycling, recovery and disposal of waste electrical and electronic equipment; extended producer responsibility organizations and individual system (third stage);

-drafting a bill on small batteries, batteries and accumulators in accordance with the best European practices and requirements of Directive 2006/66 / EU of the European Parliament and of the Council of 6 September 2006 "On batteries and accumulators and spent batteries and accumulators", which stipulates the requirements for conducting the state register, provides requirements for the State Register, in which there are must be registered entities engaged in the collection, transportation, preparation for reuse, recycling, recovery and disposal of waste small batteries, batteries and accumulators (third stage);

-planning of measures to monitor and control the inclusion of the indicator "the number of licenses/permits issued for the collection and transportation of medical waste, units".

In our opinion, along with the carefully considered points mentioned above, it is necessary to have a more thorough approach to reflecting the significant role of the transport and logistics component in this National Strategy. First of all, it should be clear that in order to change the attitude towards waste and, consequently, the transition to an effective waste management policy, transportation in the area should be seen as inseparable unity with the broader concept of logistics operations (with socalled reverse logistics). We can draw an analogy with the role of feedback in any management system: it is this role of the transport and logistics component in the field of 
waste management. Therefore, the content of strategies (both the National Strategy and individual regional strategies, for example [3031]) contains additive tasks and measures related to transport and the construction of logistic schemes for waste collection. Instead, or in addition to this it is necessary to integrate transport-logistical subsystem in waste management, and in such a way that it is fully reflected at all stages of the development and implementation of the strategy (for example, it is stated in the National Strategy [29] that waste can be generated in the process of transportation of minerals; from the transport infrastructure depends on the formation of waste construction and repair, etc.), and the connection with all waste management processes, and not only mainly with the collection and transportation of waste. In other words, the appropriateness of an integrated approach, the application of which, in particular, corresponds to the priorities specified in the Strategy of Sustainable Logistics and the Action Plan [32], which are designed by the Ministry of Infrastructure of Ukraine, and the world experience in development and implementation of responsible waste management strategies [33-34].
Conclusions and suggestions.

Consequently, as a result of the research, the following conclusions can be drawn. It is substantiated that at present the reform of the waste management system is necessary by means of solving a series of interrelated organizational, economic and managerial tasks in the context of implementation of resource conservation and environmental protection policy in Ukraine. In particular, it is about the need for financial stabilization of the industry, the expediency of strengthening regulatory instruments and, at the same time, motivational instruments, etc. Based on the analysis of the relationship between these objectives and the objectives of environmental policy, in particular in the field of transport and logistics, as well as the content and constituents of waste management strategies in Ukraine, it was concluded that there is a need for an integrated approach to determine the role and place of transport-logistic component. This will increase the effectiveness of the implementation of strategies and will ultimately reduce waste management costs in the interest of all stakeholders. Our further researches will be devoted to a more detailed analysis of the reverse transport-logistics system. 


\section{REFERENCES}

1. Lyko, D. V., \& Hushchuk I. V. (2008). Problematic issues concerning waste management and utilization in the Rivne region. Ecology of the Environment and Life Safety, 5, 47-49 [in Ukrainian].

2. Ukrainian twice annually create more waste than EU citizens (2017). UNIAN, November 8, 2017. Retrieved from: https://www.unian.ua/ecology/trash/2231894-ukrajintsi-schorokuutvoryuyut-vdvichi-bilshe-vidhodiv-nij-gromadyani-krajin-es.html [in Ukrainian].

3. Environment of Ukraine for 2017 (2018). Statistical Collection. State Statistics Service of Ukraine. Ed. O. M. Prokopenko. Kyyv. [in Ukrainian].

4. Tragedy near Lviv: Village Council permanently closed the landfill in Velyki Hrybovychy (2016). New time. June 2, 2016. Retrieved from: https://nv.ua/ukr/ukraine/events/silska-radanazavzhdi-zakrila-smittjezvalishche-u-velikih-gribovichah-138483.html [in Ukrainian].

5. Burkinsky, B.V., Martyenko, A. I., \& Khumarova, N. I. (2016). Institutional aspects of administration of the sphere of natural resources use in Ukraine. Economy of Ukraine, 1, $72-83$ [in Ukrainian].

6. Martienko, A., \& Khumarova, N. (2017). Improvement of the administration system in the field of natural resources use. Economics. Ecology. Socium, 1(1), 71-81.

7. Khumarova, N. I. (2007). Resource saving as a dominant source of regional development ecology (on the example of the Seaside regions). Nowoczesnosc ponowoczesnosc spoleczenstwo obywatelskie weuropie srodkowej iwschodniej. Lublin: Wydawnictwo KUL, Vol. 2, 491-496 [in Russian].

8. Petrushenko, M. M. (2013). Forecasting and regulating the development of the national economy: socio-natural and economic contradictions. Sumy: University Book [in Ukrainian].

9. Prokopenko, O., Kysly, V., \& Shevchenko, H. (2014). Peculiarities of the natural resources economic estimation under the transformational conditions. Economical Annals-XXI, 7-8(1), 40-43.

10. Shevchenko, H., Pakhomov, V., \& Petrushenko, M. (2016). Economic and legal issues of rural and recreational land use in Ukraine. Economical Annals-XXI, 156, 54-58.

11. Orfanova, M. M., \& Ivanyk, O. I. (2016). Improvement of solid waste management system in the city of Ivano-Frankivsk. Man and the environment. Problems of neoecology, 3-4, 126-131 [in Ukrainian].

12. Kharchenko, T. B., \& Sahaydak, Yu. (2014). Improvement of the solid waste recycling system in Ukraine. Herald of Kiyv National University named Taras Shevchenko. Series: Economics, 165, 41-45 [in Ukrainian].

13. Semenenko, I. S., \& Suprunenko, O. V. (2011). The problem of household waste management in the Zakarpatska oblast in modern economic conditions. Scientific Bulletin of Uzhgorod University. Series Economics, 33(4), 114-119 [in Ukrainian].

14. Khumarova, N. I. (2008). Ecologization of innovative strategies to reduce the waste of production. Journal of economics of science of Ukraine, 2, 155-160 [in Russian].

15. Bing, X., Bloemhof-Ruwaard, J. M. \& van der Vorst, J. G. A. J. (2014). Sustainable reverse logistics network design for household plastic waste. Flexible Services and Manufacturing Journal, 26, 119. doi:10.1007/s10696-012-9149-0.

16. Das, S., \& Bhattacharyya, B. K. (2015). Optimization of municipal solid waste collection and transportation routes. Waste Management, 43, 9-18. doi:10.1016/j.wasman.2015.06.033.

17. Jalil, E. E. A., Grant, D. B., Nicholson, J. D. \& Deutz, P. (2016). Reverse logistics in household recycling and waste systems: a symbiosis perspective. Supply Chain Management: An International Journal, 21(2), 245-258. doi:10.1108/SCM-02-2015-0056.

18. Peri, G., Ferrante, P., La Gennusa, M., Pianello, C., \& Rizzo, G. (2018). Greening MSW management systems by saving footprint: The contribution oft he waste transportation. Journal of Environmental Management, 219(1), 74-83. doi:10.1016/j.jenvman.2018.04.098.

19. Brahinsky, V. V. (2011). Development of transport-logistic system as a form of realization of transit potential of Ukraine. Public Administration: Theory and Practice: Scien. prof. 
journ. of National acad. of Gov. Man. under the President of Ukraine, 2, 12. Retrieved from: http://www.academy.gov.ua/ej/ej14/txts/Braginskiy.pdf [in Ukrainian].

20. Lyfar, V. V. (2017). Development of transport logistics in the regional system of product flow management. Marketing and management of innovations, 4, 176-187 [in Ukrainian].

21. Hryhorak, M. Yu., \& Chychkan-Khlipovka, Yu. M. (2007). Theoretical principles of reversible logistics. Bulletin of the National University "Lviv Polytechnic", 580, 36-42 [in Ukrainian].

22. Kriventsev, O. (2018). The problem of domestic waste management is relevant and quite acute for Ukraine. ANK-NEWS Ukraine, 5, 3-4 [in Ukrainian].

23. Solid domestic waste in Ukraine: Potential of development (2015). Scripts of the development of the solid waste management industry. Final report. IFC, World Bank Group.

24. Stankevich-Volosyanchuk, O. (2010). Management of solid waste - the state and prospects. Waste Management in Ukraine: Newsletter, December, 1, 3-4 [in Ukrainian].

25. Petrushenko, M. M., \& Shevchenko, H. M. (2018). Regulation of ecologic-andeconomical risks and the responsibility for human well-being: for example of waste management. Economic Innovations, 3(68), 165-175.

26. Khumarova, N. I. (2010). Institutional mechanism for implementing ecologically oriented strategic plans for the development of territorial economic and ecological systems. Economic innovation, 41, 281-289 [in Ukrainian].

27. In summer, the construction of a waste recycling plant will start in Lviv (2018). That is Lviv. May, 1. Retrieved from: https://inlviv.in.ua/lviv/vlitku-u-lvovi-startuye-budivnytstvosmittyepererobnogo-zavodu [in Ukrainian].

28. Umwelt Ukraine, LLC (2018). Retrieved from: http://www.umwelt.com.ua/.

29. National Strategy for Waste Management in Ukraine until 2030 (2017). The CMU resolution dated November, 8. №820-p. Retrieved from: https://zakon.rada.gov.ua/laws/show/8202017-\%D1\%80\#n8. [in Ukrainian].

30. Integrated Solid Waste Management (SWM) Strategy in Tulchin Target Region (2012). Swiss-Ukrainian project DESPRO. Tulchin. Retrieved from: http://despro.org.ua/despro/ [in Ukrainian].

31. Waste Management Strategy in Lviv oblast by 2030 (2017). Lviv Oblast State Administration. 2017.2 Retrieved from: http://gw1.oblrada.lviv.ua/rada/rishennialor.nsf/52889c345440ab40c2257b55007e8f51/7ccf6ba2bc2 c5a79c225820300531eb7/\$FILE/580_dod.pdf [in Ukrainian].

32. Sustainable Logistics Strategy and Action Plan for Ukraine. Draft for consideration (2017). Ministry of Infrastructure of Ukraine; World Bank Group. Retrieved from: https://mtu.gov.ua/files/Logistics.pdf [in Ukrainian].

33. Newfoundland and Labrador waste management strategy (2002). Department of environment of Newfoundland and Labrador, April. Retrieved from: https://www.mae.gov.nl.ca/publications/pswms/wastemanagementstrategy_apr2002.pdf.

34. A sustainable waste management strategy drives life-cycle building benefits (2012). WM: Think Green. Retrieved from: https://www.wm.com/documents/pdfs-for-servicessection/Sustainable_strategy.pdf. 


\section{ЛІТЕРАТУРА}

1. Лико Д. В., Гущук I. В. Проблемні питання щодо поводження з відходами та їх утилізації в Рівненській області. Екологія довкілля та безпека життєдіяльності. 2008. №5. C. 47-49.

2. Українці щороку утворюють вдвічі більше відходів, ніж громадяни країн ЄС // УНІАН, 08 листопада 2017. URL: https:/www.unian.ua/ecology/trash/2231894-ukrajintsischoroku-utvoryuyut-vdvichi-bilshe-vidhodiv-nij-gromadyani-krajin-es.html.

3. Довкілля України за 2017 рік: Статистичний збірник / за ред. О.М. Прокопенко. Київ: Державна служба статистики України. 2018. 225 с.

4. Трагедія під Львовом: Сільська рада назавжди закрила сміттєзвалище у Великих Грибовичах. Новое время. 2 червня 2016. URL: https://nv.ua/ukr/ukraine/events/silska-radanazavzhdi-zakrila-smittjezvalishche-u-velikih-gribovichah-138483.html.

5. Буркинський Б. В., Мартієнко А. I., Хумарова Н. I. Інституційні аспекти адміністрування сфери природокористування в Україні. Економіка України. 2016. № 1. C. $72-83$.

6. Martienko A., Khumarova N. Improvement of the administration system in the field of natural resources use. Economics. Ecology. Socium. 2017. № 1(1). PP. 71-81.

7. Хумарова Н. И. Ресурсосбережение как доминанта экологизации регионального развития (на примере Приморских регионов). Nowoczesnosc ponowoczesnosc spoleczenstwo obywatelskie weuropie srodkowej iwschodniej. Lublin: Wydawnictwo KUL. 2007. Toм 2. C. 491496.

8. Петрушенко М. М. Прогнозування та регулювання розвитку національної економіки: соціоприродні й економічні протиріччя. Суми: Університетська книга. 2013. 336 с.

9. Prokopenko O., Kysly V., Shevchenko H. Peculiarities of the natural resources economic estimation under the transformational conditions. Economical Annals-XXI. 2014. № 7-8(1). PP. 4043.

10. Shevchenko H., Pakhomov V., Petrushenko M. Economic and legal issues of rural and recreational land use in Ukraine. Economical Annals-XXI. № 156. PP. 54-58.

11. Орфанова М. М., Іваник О. І. Удосконалення системи поводження 3 твердими побутовими відходами в місті Івано-Франківськ. Людина та довкілля. Проблеми неоекології. 2016. № 3-4. C. 126-131.

12. Харченко Т. Б., Сагайдак Ю. Удосконалення системи переробки твердих побутових відходів в Україні. Вісник Киівського національного університету ім. Тараса Шевченка. Серія: Економіка. 2014. Вип. 165. С. 41-45.

13. Семененко I. С., Супруненко О. В. Проблема поводження із побутовими відходами в Закарпатській області в сучасних умовах господарювання. Науковий вісник Ужгородського університету. Серія Економіка. 2011. Вип. 33. Ч. 4. С. 114-119.

14. Хумарова Н. И. Экологизация инновационных стратегий снижения отходоемкости производств. Вісник економічної науки України. 2008. № 2. С. 155-160.

15. Bing X., Bloemhof-Ruwaard J. M., van der Vorst J. G. A. J. Sustainable reverse logistics network design for household plastic waste. Flexible Services and Manufacturing Journal. 2014. № 26. PP. 119. https://doi.org/10.1007/s10696-012-9149-0.

16. Das S., Bhattacharyya B. K. Optimization of municipal solid waste collection and transportation routes. Waste Management. 2015. № 43. PP. 9-18. https://doi.org/10.1016/j.wasman.2015.06.033.

17. Jalil E. E. A., Grant D. B., Nicholson J. D., Deutz P. Reverse logistics in household recycling and waste systems: a symbiosis perspective. Supply Chain Management: An International Journal. 2016. Vol. 21. Issue 2. PP. 245-258. https://doi.org/10.1108/SCM-022015-0056.

18. Peri G., Ferrante P., La Gennusa M., Pianello C., Rizzo G. Greening MSW management systems by saving footprint: The contribution of the waste transportation. Journal of Environmental 
Management. 2018. № 219(1). PP. 74-83. https://doi.org/10.1016/j.jenvman.2018.04.098.

19. Брагінський В. В. Розвиток транспортно-логістичної системи як форма реалізації транзитного потенціалу України. Державне управління: теорія і практика : наук. фах. вид. Нац. акад. держ. упр. при Президентові Украӥни. 2011. №2. 12 с. URL: http://www.academy.gov.ua/ej/ej14/txts/Braginskiy.pdf.

20. Лифар В. В. Розвиток транспортної логістики в регіональній системі обслуговування товарних потоків. Маркетинг і менеджмент інновацій. 2017. № 4. С. 176187.

21. Григорак М. Ю., Чичкан-Хліповка Ю.М. Теоретичні засади реверсивної логістики. Вісник Наџіонального університету «Львівська політехніка». 2007. № 580. С. 36-42.

22. Крівенцев О. Проблема поводження з побутовими відходами є актуальною і досить гострою для України. AHK-NEWS Україна. 2018. № 5 (Липень-Серпень). С. 3-4.

23. Тверді побутові відходи в Україні: Потенціал розвитку. Сценарії розвитку галузі поводження 3 твердими побутовими відходами. Підсумковий звіт. IFC, Група Світового банку. 2015. $110 \mathrm{c.}$

24. Станкевич-Волосянчук О. Поводження з твердими побутовими відходами - стан і перспективи. Управління відходами в Україні: інформаційний бюлетень. 2010, грудень. № 1. C. $3-4$.

25. Petrushenko M. M., Shevchenko H. M. Regulation of ecologic-and-economical risks and the responsibility for human well-being: for example of waste management. Economic Innovations. 2018. № 3(68). PP. 165-175.

26. Хумарова Н. I. Інституційний механізм реалізації екологоорієнтованих стратегічних планів розвитку територіальних економіко-екологічних систем. Економічні інновачіï. 2010. № 41. С. 281-289.

27. Влітку у Львові стартує будівництво сміттєпереробного заводу. То є Львів. 2018, 1 травня. URL: https://inlviv.in.ua/lviv/vlitku-u-lvovi-startuye-budivnytstvo-smittyepererobnogozavodu.

28. Умвельт Україна, TOB. 2018. URL: http://www.umwelt.com.ua/.

29. Національна стратегія управління відходами в Україні до 2030 року: Розпорядження КМУ від 8 листопада 2017 p. № 820-p. URL: https://zakon.rada.gov.ua/laws/show/820-2017-\%D1\%80\#n8.

30. Стратегія інтегрованого поводження з твердими побутовими відходами (ТПВ) у Тульчинському цільовому регіоні / Швейцарсько-український проект DESPRO. Тульчин. 2012. 45 c. URL: http://despro.org.ua/despro/.

31. Стратегія управління відходами у Львівській області до 2030 року / Львівська обласна державна адміністрація. $2017 . \quad 40 \mathrm{c.}$ URL: http://gw1.oblrada.lviv.ua/rada/rishennialor.nsf/52889c345440ab40c2257b55007e8f51/7ccf6ba2bc2 c5a79c225820300531eb7/\$FILE/580_dod.pdf.

32. Стратегія сталої логістики та План дій для України. Проект для розгляду / Міністерство інфраструктури України; World Bank Group. 2017. 88 с. URL: https://mtu.gov.ua/files/Logistics.pdf.

33. Newfoundland and Labrador waste management strategy / Department of environment of Newfoundland and Labrador. Apr. 2002. 23 p. URL: https://www.mae.gov.nl.ca/publications/pswms/wastemanagementstrategy_apr2002.pdf.

34. A sustainable waste management strategy drives life-cycle building benefits / WM: Think Green. 2012. URL: https://www.wm.com/documents/pdfs-for-servicessection/Sustainable_strategy.pdf. 